\title{
TUJUAN HIDUP DALAM PERSPEKTIF AL-QUR'AN
}

\section{Ibrahim Bafadhol}

Dosen Prodi IAT STAI Al-Hidayah Bogor

\begin{abstract}
Abstrak
Dalam perspektif Islam, bahwa sesungguhnya Allah menciptakan alam ini untuk ber-khidmah (melayani kepentingan) manusia. Dalam rangka menyelenggarakan kekhalifahan di muka bumi, Allah telah menundukkan alam semesta demi kemaslahatan manusia dan demi kemudahan mereka dalam menjalankan peran besarnya, khilafah fil ardh.Tidak dapat dipungkiri bahwa manusia adalah makhluk yang telah Allah istimewakan dari seluruh makhluk yang ada. Konsekwensinya, Allah Ta'ala tidaklah menciptakan manusia dan mengutamakannya dari seluruh makhluk yang ada kecuali untuk sebuah tujuan yang besar dan misi yang agung. Tentang hal ini, al-Qur'an telah menginformasikannya dengan sangat jelas:

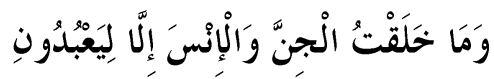

"Dan Aku tidaklah menciptakan jin dan manusia melainkan supaya mereka beribadah kepada-Ku." (QS. adz-Dariyat: 56). Artikel ini hendak mendeskripsikan dengan lebih terinci bagaimanakah hakikat ibadah dalam Islam dan bagaimana mengimplementasikan ibadah tersebut dalam kehidupan seorang Muslim.
\end{abstract}

Keyword: Tujuan hidup, ibadah, khilafah fil ardh

\section{A. Pendahuluan}

Allah Subhanahu wa Ta'ala telah menegaskan bahwa Ia tidaklah menciptakan langit, bumi dan semua yang ada di alam semesta dengan main-main atau tanpa tujuan yang benar. Dan hal ini sangat bertentangan dengan sifat Allah Ta'ala yang Maha bijaksana (alHakim).

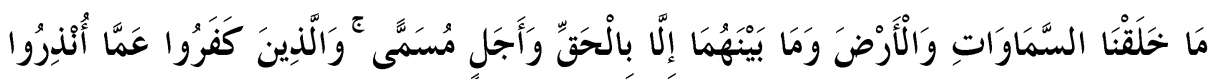

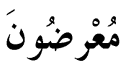


"Dan Kami tiada menciptakan langit dan bumi dan apa yang ada di antara keduanya melainkan dengan tujuan yang benar dan dalam waktu yang ditentukan." (QS. al-Ahqaf: 3)

Demikian pula halnya dengan manusia, makhluk yang Allah istimewakan dan telah diberi kelebihan dari sekalian makhluk yang ada. Allah Ta'ala tidaklah menciptakan manusia kecuali untuk sebuah tujuan yang besar dan risalah (misi) yang agung. Mustahil Allah menciptakan manusia tanpa suatu maksud yang urgen.

Allah telah membantah sangkaan yang salah dari sebagian manusia sebagaimana firman-Nya:

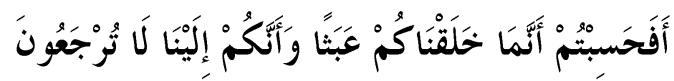

"Maka apakah kamu mengira, bahwa sesungguhnya Kami menciptakan kamu secara main-main (saja), dan bahwa kamu tidak akan dikembalikan kepada Kami?" (QS. Al Mu'minun : 115).

Tentang tujuan hidup manusia, al-Qur'an al-Karim telah memaparkannya dengan sangat jelas. Allah Ta'ala berfirman:

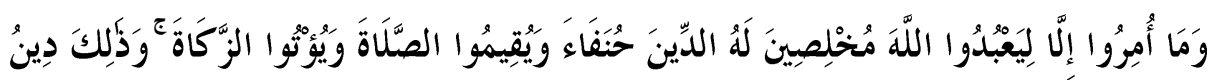

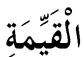

"Dan mereka tidaklah disuruh kecuali supaya menyembah Allah dengan memurnikan ketaatan kepada-Nya dalam menjalankan agama yang lurus, dan supaya mereka mendirikan shalat serta menunaikan zakat; dan yang demikian itulah agama yang lurus." (QS. al-Bayyinah: 5)

Tentang surat adz-Dzariyat ayat 56 di atas, Imam ath-Thabari berkata, "Pendapat yang paling tepat tentang ta'wil ayat ini adalah apa yang kami kutip dari Ibn 'Abbas yaitu, "Tidaklah Kami ciptakan jin dan manusia kecuali untuk menghambakan diri kepada Kami dan merendahkan diri terhadap perintah Kami." 44 dengan

Sedangkan sebagian ahli tafsir yang lain memaknai ayat di atas

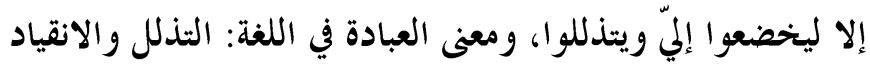

\footnotetext{
${ }^{44}$ Muhammad bin Jarir at-Thabari, Jami' al-Bayan fi Ta 'wil al-Qur'an, Mu'assasah ar-Risalah, Riyadh, jilid 22, hlm. 445.
} 
"kecuali agar mereka tunduk kepada-Ku dan menghinakan diri." Sedangkan ma'na ibadah secara bahasa adalah kehinaan dan kepatuhan. ${ }^{45}$ Ayat ini menjelaskan dengan gamblang tentang tujuan penciptaan manusia.

\section{B. Definisi Ibadah}

Secara etimologi, kata ibadah (العبادة) dalam bahasa Arab merupakan bentuk mashdar dari kata عبد yang memiliki arti:

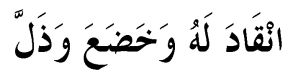

(patuh terhadapnya, tunduk dan menghinakan diri. ${ }^{46}$

Ar-Raghib al-Ashfahani berkata:

العبودية : إظهار التذلل ، و العبادة أبلغ منها لأنها غاية التنلل و لا بستحقها إلا من له غاية

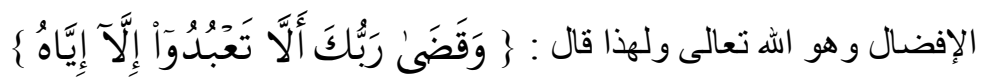

"Al- 'Ubudiyyah bermakna menampakkan kehinaan, sedangkan ibadah lebih dalam lagi karena ia adalah puncak penghinaan diri dan hal ini tidak layak dipersembahkan kecuali kepada Dzat yang memiliki puncak karunia yaitu Allah Ta'ala. Oleh karena itu Allah berfirman:

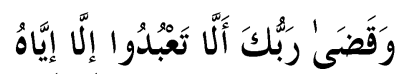

"Dan Tuhanmu telah memerintahkan supaya kamu jangan menyembah selain Dia." (QS. al-Isra': 23) ${ }^{47}$

Adapun secara terminologi, maka sebagian ulama mendefinisikan ibadah dengan:

$$
\text { اسم جامع لكل ما يحبه الله ويرضاه من الأقوال والأعمال الباطنة والظاهرة }
$$

"Suatu istilah yang mencakup segala sesuatu yang dicintai Allah dan diridhai-Nya, baik berupa perkatan maupun perbuatan, yang tersembunyi (batin), maupun yang nampak (lahir)."

\footnotetext{
${ }^{45}$ Al-Husain bin Mas'ud al-Bagowi, Ma'alim at-Tanzil, Dar at-Thayyibah, Riyadh, jilid 7, hlm. 381 .

${ }^{46}$ Dr. Ibrahim Anis, al-Mu'jam al-Wasith, Dar al-Ma'arif, Kairo, hlm. 579.

${ }^{47}$ Ar-Raghib al-Ashfahani, Mufradaat al-Qur'an, al-Maktabah asy-Syamilah., hlm. 938

${ }^{48}$ Ahmad ibn Abdul Halim al-Harrani, al- 'Ubudiyah, Maktabah Dar al-Balagh, Kairo, hlm. 6
} 
bahwa makna ibadah sangatlah luas. Tidak hanya terbatas pada ritualritual khusus saja.

Dengan demikian dapat dikatakan bahwa mendirikan shalat, berzakat, berpuasa, berhaji, ucapan yang jujur, menunaikan amanah, berbakti kepada kedua orang tua, menyambung tali kekerabatan, menepati janji, memerintahkan berbuat ma'ruf, mencegah kemungkaran, jihad melawan kaum kafir dan kaum munafik, berlaku baik terhadap tetangga maupun anak yatim dan orang miskin juga terhadap hewan ternak, berdoa, berzikir, membaca Al Quran, dan hal semisal itu merupakan bentuk-bentuk ibadah.

Demikian pula, cinta kepada Allah dan Rasul-Nya, takut kepada Allah, bertaubat kepada-Nya, memurnikan agama hanya untuk-Nya, sabar atas ketetapan-Nya, bersyukur atas segenap nikmat-Nya, ridha atas keputusan-Nya, bertawakal kepada-Nya, mengharap rahmat-Nya, takut akan azab-Nya, serta contoh semisal itu merupakan bentukbentuk ibadah kepada Allah.

Jadi, ibadah dalam Islam jangkauannya menyentuh semua aspek kehidupan. Tidak hanya terbatas pada ritual-ritual (asy-sya'aa'ir) yang sudah biasa kita kenal berupa shalat, puasa, zakat dan haji. Akan tetapi mencakup pula seluruh gerak dan semua aktivitas yang dapat meningkatkan kualitas kehidupan manusia atau mensejahterakan manusia.

Semua pekerjaan yang bermanfaat yang dilakukan seorang muslim demi pengabdiannya kepada masyarakat, atau menolong personil-personilnya, khususnya mereka yang tergolong kaum dhu'afa' dan papa juga merupakan salah satu bentuk ibadah.

Oleh karena itu, kita dapati banyak hadits-hadits yang menganjurkan bersedekah setiap hari di mana matahari terbit padanya. Menyingkirkan duri dari tengah jalan adalah ibadah, membantu seorang yang lemah untuk menaiki kendaraannya atau membantu mengangkatkan barang mereka ke kendaraanya adalah sedekah, bahkan senyun anda di hadapan saudara anda adalah sedekah. Juga kata-kata yang baik adalah sedekah, dan semua hal yang baik (ma'ruf) adalah sedekah. Lebih dari itu, seorang yang menyalurkan syahwatnya pada tempat yang halal tercatat sebagai ibadah dan akan mendapatkan pahala atas perbuatannya itu. 
Ketika para sahabat merasa heran atas pernyataan beliau, Rasulullah shallallahu 'alaihi wasallam bersabda, "Bukankah jika ia menyalurkan syahwatnya pada tempat yang haram ia akan mendapatkan dosa?" Mereka menjawab, "Ya, benar wahai Rasulullah." Maka beliau bersabda, "Maka begitu pula jika ia menyalurkan syahwatnya pada tempat yang halal ia akan mendapatkan pahala." (HR. Muslim)

Termasuk dalam cakupan ibadah adalah usaha seseorang untuk menafkahi diri dan keluarganya dari yang halal. Islam menganggap bekerjanya seorang muslim untuk menukupi dirinya dan keluarganya dengan rezeki yang halal sehingga menjaga mereka dari meminta-minta termasuk suatu ibadah. Bahkan Rasulullah shallallahu 'alaihi wasallam menilai orang yang melakukan itu berada fi sabilillah, ya'ni seperti seorang mujahid yang sedang berjuang di jalan Allah. ${ }^{51}$

Bahkan Islam memotivasi para pemeluknya untuk memakmurkan bumi Allah ini dengan berbagai macam tanaman dan hasil bumi serta menjanjikan pahala bagi setiap orang yang menanam sebuah biji atau sebuah tunas. Nabi 能 bersabda:

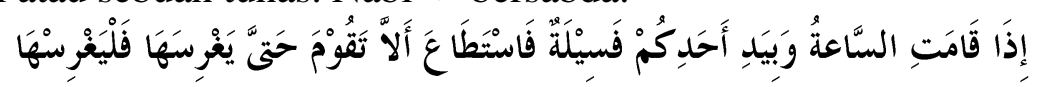

"Jika kiamat datang, sementara di tangan salah seorang kalian ada biji palem, lalu ia mempunyai kesempatan untuk menaneamkannya sebagai sebelum kiamat terjadi, hendaklah ia tanamkan dan ia akan mendapatkan pahala dengan hal itu." (HR. Ahmad)

Hadits ini memberikan makna yang demikian luas untuk ibadah. Sebagaimana yang telah dimaklumi, bahwa menanam benih adalah akifitas dunia, akan tetapi karena ia berdampak positif dan memberi kemanfaatan bagi manusia maka Allah Ta'ala memberikan pahala atas amal tersebut.

Tidak hanya menanam benih, akan tetapi semua aktifitas pemakmuran bumi adalah ibadah dalam pandangan Islam. Hal ini sebagaimana firman Allah Ta'ala:

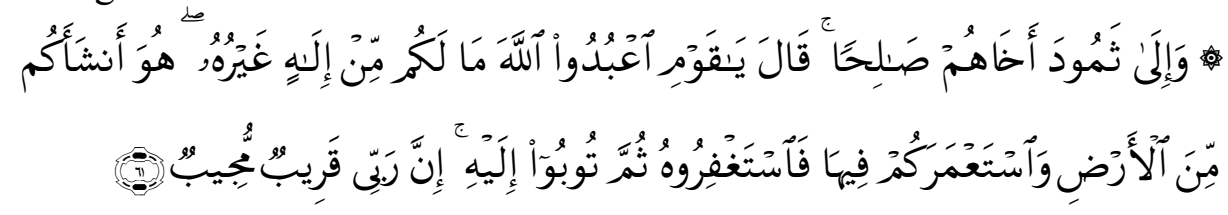

\footnotetext{
${ }^{51}$ Dr. Yusuf al Qardhawi, Karakteristik Islam, Kajian Analistik, Risalah Gusti, Surabaya, 1995, hlm.130.
} 
"Dan kepada Tsamud Kami utus saudara mereka Shaleh. Shaleh berkata: "Hai kaumku, sembahlah Allah, sekali-kali tidak ada bagimu Tuhan selain Dia. Dia telah menciptakan kalian dari bumi (tanah) dan menjadikan kalian sebagai pemakmurnya." (QS. Hud: 61).

Seorang hamba yang telah mewujudkan pengabdian atau ibadahnya kepada Allah semata dan beristiqomah di atas hal ini maka ia berada di atas jalan yang lurus atau shirath al-mustaqiim. Sebagaimana firman Allah Ta'ala:

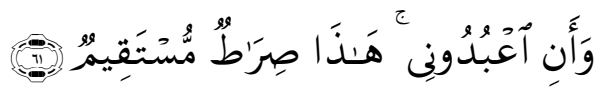

"Dan hendaklah kamu menyembah-Ku. Inilah jalan yang lurus".(Q.S Yasiin [36]: 61)

\section{Pembagian Ibadah}

Sebagian ulama membagi ibadah menjadi tiga, yaitu ibadah hati, ibadah lisan dan ibadah fisik. Ibadah hati ('ibadah qalbiyyah) seperti cinta kepada Allah dan Rasul-Nya (mahabbah), takut kepada Allah (khauf), ikhlas kepada Allah, bertawakkal kepada-Nya, mengharap akan rahmat-Nya, bersyukur kepada-Nya dan bersabar atas qadha'Nya. ${ }^{52}$

Sedangkan ibadah lisan seperti berdzikir menyebut asma'Allah, tilawah al-Qur'an, bershalawat kepada Rasulullah shallallahu 'alaihi wasallam, mengucapkan salam atau menjawabnya, mengajarkan ilmu yang bermanfaat, menyampaikan nasihat, menyuruh kepada yang ma'ruf dan mencegah dari yang mungkar serta amal-amal lainnya yang terkait dengan lisan.

Adapun ibadah fisik ('ibadah badaniyyah) meliputi semua amal kebajikan yang dilakukan oleh anggota badan seperti shalat, zakat, puasa, haji, berbakti kepada orang tua, berbuat baik kepada kerabat, anak yatim, orang miskin, musafir, melangkahkan kaki ke tempattempat yang dicintai Allah, menyingkirkan gangguan dari jalan dan amal-amal lain yang terkait dengan dengan fisik.

Sebagian lagi membagi ibadah menjadi dua yaitu 'ibadah mahdhoh dan 'ibadah ghairu mahdhoh. Ibadah mahdhoh adalah ibadah

\footnotetext{
52 Shalih bin Fauzan, Aqidah Tauhid Kitab at-Tauhid lis Shaff al-Awwal, penerbit Ummul Qura, Jakarta, 2012, hlm. 60.

${ }^{53}$ Ibid, hlm. 61.
} 
yang bersifat ritual (sya'aa'ir) yang tata-cara (kaifiyat) dan bentuknya telah diajarkan dan dicontohkan oleh Rasulullah shallallahu 'alaihi wasallam seperti bersuci, shalat, puasa, zakat, haji, 'umroh, i'tikaf, adzan, doa-doa dan dzikir yang khusus, berkurban, aqiqah dan sebagainya.

Sedangkan 'ibadah ghairu mahdhoh adalah ibadah yang bersifat umum atau semua amal kebaikan yang diridhai dan dicintai Allah Ta'ala seperti menanam tanam-tanaman yang bermanfaat bagi manusia, memudahkan urusan kaum muslimin, tolong menolong dalam kebaikan, dan sebagainya. Semua aktivitas seorang muslim jika diniatkan untuk mendekatkan diri kepada Allah atau sebagai sarana yang dapat membantu mewujudkan hal itu adalah ibadah. Bahkan kebiasaan yang mubah (al-'adah) pun bernilai ibadah jika diniatkan sebagai bekal untuk taat kepada Allah. Misalnya, makan dan minum, tidur, jual beli, bekerja mencari nafkah dan sebagainya. ${ }^{54}$

\section{Tugas Kekhalifahan di Muka Bumi}

Dalam konteks hubungan dengan Rabb-nya manusia adalah hamba Allah. Sedangkan dalam konteks hubungan dengan alam semesta (kaun) ia adalah khalifah. Oleh karena itu dapat dikatakan bahwa tujuan hidup manusia adalah menunaikan penghambaan dan pengabdian -dalam makna yang luas- kepada Allah Ta'ala. Sedangkan perannya di muka bumi adalah sebagai khalifah (pemimpin) di alam semesta ini.

Dalam pandangan Islam manusia adalah makhluk yang istimewa, makhluk yang sangat dimuliakan. Allah telah mengisimewakan, memuliakan dan mengutamakan manusia di atas makhluk makhluk-Nya yang lain. Diantara bentuk pengistimewaan manusia itu adalah:

\section{Dijadikannya sebagai Khalifah di muka bumi}

Allah berfirman:

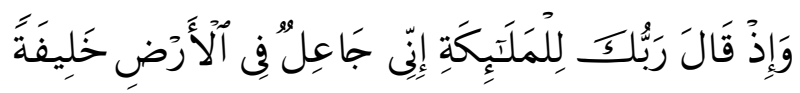

${ }^{54}$ Lihat: Sahlih bin Fauzan, Aqidah Tauhid, hlm. 62. 
"Dan ingatlah ketika Tuhanmu berfirman kepada para malaikat, "Sesungguhnya Aku hendak menjadikan seorang khalifah di muka bumi." (QS. al-Baqarah: 30)

Islam telah memproklamirkan kemuliaan manusia dengan menjadikannya sebagai khalifah Allah di atas bumi ini. Ini adalah sebuah kedudukan yang membuat para malaikat bedecak kagum, lantaran kedudukan itu tidak diberikan kepada mereka, tetapi justru diberikan Allah kepada manusia.

"Ingatlah ketika Tuhanmu berfirman kepada para malaikat, "Sesungguhnya Aku hendak menjadikan seorang khalifah di muka bumi." Mereka berkata: "Mengapa Engkau hendak menjadikan (khalifah) di bumi itu orang yang akan membuat kerusakan padanya dan menumpahkan darah, padahal kami senantiasa bertasbih dengan memuji Engkau dan mensucikan Engkau?" Allah berfirman: "Sesungguhnya Aku mengetahui apa yang tidak kalian ketahui." Dan Allah mengajarkan kepada Adam nama-nama (benda-benda) seluruhnya, kemudian mengemukakannya kepada para malaikat lalu berfirman: "Sebutkanlah kepada-Ku nama benda-benda itu jika kalian memang benar!" Mereka menjawab: "Maha suci Engkau, tidak ada yang kami ketahui selain dari apa yang telah Engkau ajarkan kepada kami; Sesungguhnya Engkau-lah yang Maha mengetahui lagi Maha Bijaksana." (QS. al-Baqarah: 30-33)

Allah Ta'ala telah menobatkan manusia sebagai khalifah di muka bumi, dan agar manusia mampu menjalankan tugas besar ini Allah telah mengaruniainya akal dan ilmu pengetahuan yang menjadikannya dapat mengungguli para malaikat. ${ }^{55}$

\section{Diciptakannya dalam sebaik-baik bentuk}

Islam juga telah memprolamirkan bahwa Allah telah memuliakan manusia dalam bentuk dan ciptaan yang terbaik sebagaimana Allah berfirman:

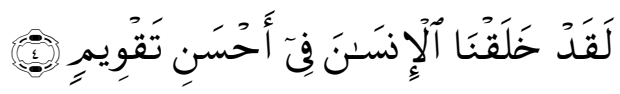

${ }^{55}$ Al-Qardhawi, Karakteristik Islam, hlm. 80. 
Pemuliaan ini tidak hanya untuk pribadi Adam 'alaihis salam saja, tetapi pemuliaan jenis manusia pada umumnya. Allah mengistimewakan mereka sebagaimana Dia telah memuliakan Adam 'alaihis salam, dengan keistimewaan yang berupa akal, ilmu dan ruh. Dan Allah menjadikan mereka khalifah sebagaimana Dia telah menjadikan Adam 'alaihis salam sebagai khalifah-Nya di atas bumi. ${ }^{56}$ Karenanya, al-Qur'an memproklamirkan kemuliaan seluruh manusia melalui firman-Nya:

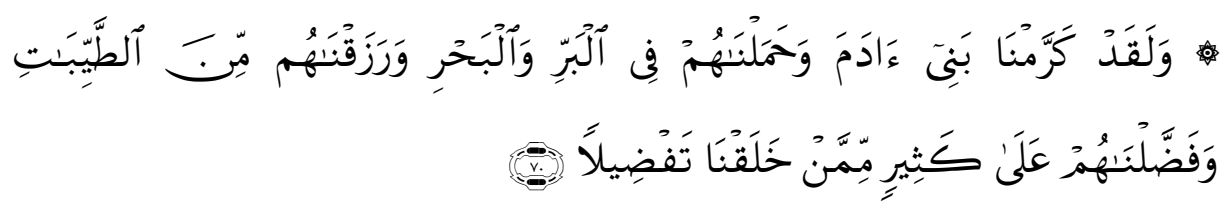

"Dan sesungguhnya telah Kami muliakan anak-anak Adam, Kami angkut mereka di daratan dan di lautan, dan Kami beri mereka rezeki dari yang baik-baik, dan Kami lebihkan mereka dengan kelebihan yang sempurna atas kebanyakan makhluk yang telah Kami ciptakan." (QS. al-Israa': 70)

\section{Alam semesta seluruhnya ditundukkan untuk kepentingan manusia}

Menurut pandangan Islam, termasuk karunia pemuliaan Allah bagi manusia bahwa Dia menjadikan seluruh alam ini khidmah (tunduk demi kepentingan) manusia. Dalam rangka menyelenggarakan kekhalifahan di muka bumi Allah pun menundukkan alam semesta, langit, bumi, matahari, bulan, malam, siang, air, lautan, tetumbuhan, segala jenis hewan, dan juga benda-benda mati, semuanya tunduk demi kemaslahatan manusia dan demi kemudahan mereka dalam menjalankan peran besarnya, khilafah fil ardh.

Allah berfirman kepada manusia:

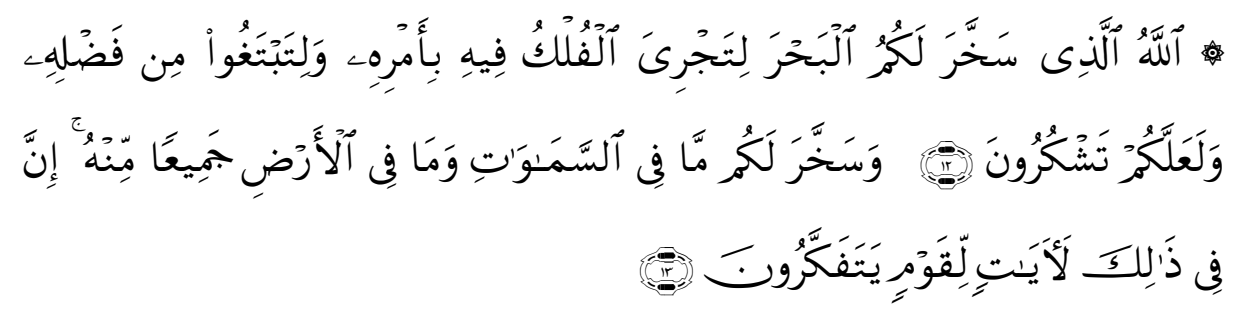

${ }^{56}$ Ibid. Hlm. 83. 
"Allah-lah yang menundukkan lautan untukmu supaya kapal-kapal dapat berlayar padanya dengan seizin-Nya dan supaya kamu dapat mencari karunia-Nya dan agr kamu bersyukur. Dan Dia telah menundukkan untukmu apa yang di langit dan di bumi semuanya, (sebagai rahmat) dari-Nya. Sesungguhnya pada yang demikian itu benar-benar terdapat tanda-tanda (kekuasaan Allah) bagi kaum yang berfikir." (QS. Jatsiyah: 12-13)

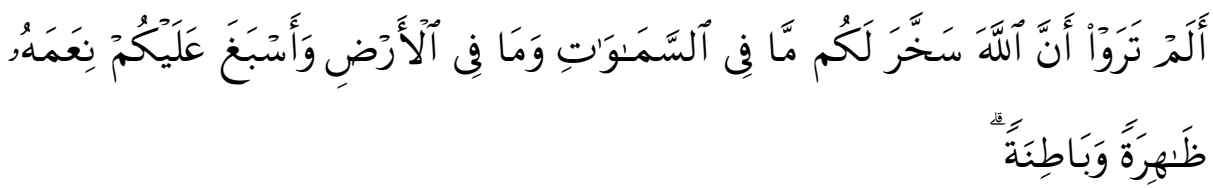

"Tidakkah kamu perhatikan bahwa Allah telah menundukkan untuk (kepentingan) mu apa yang di langit dan di bumi dan menyempurnakan untukmu nikmat-nikmat-Nya yang lahir dan yang batin." (QS. Luqman: 20)

"Dan di antara manusia ada yang membantah tentang (keesaan) Allah tanpa ilmu atau petunjuk dan tanpa kitab yang memberi penerangan. Allah-lah yang telah menciptakan langit dan bumi dan menurunkan air hujan dari langit, kemudian Dia mengeluarkan dengan air hujan itu berbagai buah-buahan sebagai rezki untukmu; dan Dia telah menundukkan bahtera bagimu supaya bahtera itu berlayar di lautan dengan kehendak-Nya, dan Dia telah menundukkan (pula) bagimu sungai-sungai. Dan Dia telah menundukkan (pula) untukmu matahari dan bulan yang terus menerus beredar (dalam orbitnya); dan telah menundukkan untukmu malam dan siang. Dan Dia telah memberikan kepadamu (keperluanmu) dan segala apa yang kamu minta kepadaNya. dan jika kamu menghitung nikmat-nikmat Allah, niscaya kamu tidak dapat menghinggakannya. Sesungguhnya manusia itu sangat zalim terhadap dirinya dan sangat mengingkari (nikmat Allah)." (QS. Ibrahim: 32-34)

Dengan semua keistimewaan di atas sesungguhnya Allah hendak mempersiapkan manusia untuk memikul tanggung jawab khilafah dan amanat taklif (tugas-tugas keagamaan), sebuah amanat yang sangat berat dan agung hingga al-Qur'an mengungkapkannya dengan sebuah gambaran yang menakjubkan, yakni firman Allah: 


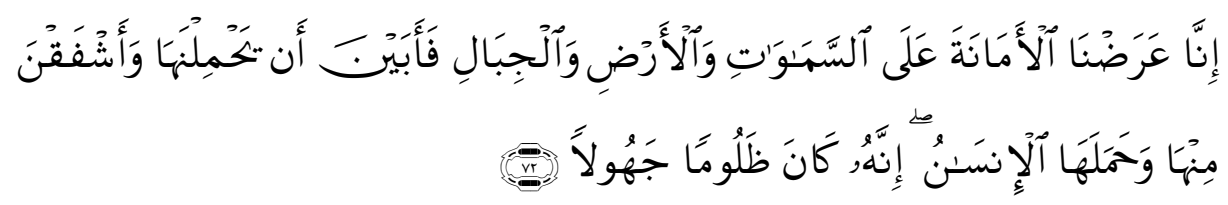

"Sesungguhnya Kami telah menawarkan amanat kepada langit, bumi dan gunung-gunung, akan tetapi semuanya enggan untuk memikul amanat itu dan mereka khawatir akan mengkhianatinya, lalu dipikullah amanat itu oleh manusia. Sesungguhnya manusia itu amat zalim dan amat bodoh." (QS. al-Ahzab: 72)

Dengan demikian, manusialah yang telah dipilih oleh Allah untuk memikul suatu amanat yang besar yaitu taklif (tugas-tugas keagamaan) dan pelaksanaan khilafah sesuai dengan kehendak Allah. Maka barangsiapa yang menunaikan amanat tersebut ia akan mendapat balasan yang baik dari sisi Allah Ta'ala, dan barangsiapa yang mengkhianati amanat tersebut maka ia akan mendapat balasan yang buruk, dan sekali-kali Allah tidaklah menzhalimi hamba-Nya, akan tetapi hamba itu sendiri-lah yang menzhalimi dirinya. ${ }^{57}$

\section{E. Tujuan Pendidikan Islam}

Pada dasarnya tujuan pendidikan Islam tidak terlepas dari tujuan hidup manusia dalam Islam yaitu mencetak pribadi-pribadi hamba Allah yang bertakwa kepada-Nya dan dapat meraih kehidupan yang bahagia di dunia dan akhirat. Dalam konteks sosiologi, membentuk pribadi-pribadi bertakwa yang menjadi rohmatan lil'alamin. Tujuan hidup dalam Islam inilah yang dapat disebut juga sebagai tujuan akhir pendidikan Islam.

Dengan berlandaskan pada tujuan hidup yang telah dijelaskan oleh al-Qur'an, sebagian ahli pendidikan merumuskan tujuan pendidikan Islam adalah:

1. Menumbuhkan manusia-manusia yang shalih dan senantiasa mengabdi (beribadah) kepada Allah atas dasar ilmu dan petunjuk.

2. Membangun manusia-manusia yang mampu memakmurkan bumi untuk kemaslahatan bersama serta mejalankan tugas-tugas kekhalifahan di muka bumi sesuai dengan manhaj Allah dan syari'at-Nya yang lurus.

${ }^{57}$ Ibid, hlm. 63 
3. Membangun masyarakat muslim secara khusus dan ummat Islam secara umum serta menjalankan misi dakwah atau menyeru manusia ke jalan Allah.

4. Memperkuat ikatan kecintaan dan kasih sayang antara sesama anggota umat Islam di satu sisi, dan semua makhluk yang ada di sekitarnya di sisi yang lain.

5. Membentuk muslim yang membawa keselamatan bagi orang lain, saling tolong menolong dengan yang lainnya dalam permasalahanpermasalahan yang menyangkut kebaikan bersama. ${ }^{58}$

Dengan kata lain, pendidikan yang ideal dalam pandangan Islam adalah pendidikan yang memadukan iman dan ilmu pengetahuan, akhlak dan skill, kecerdasan dan ketakwaan. Inilah cikal-bakal suatu bangsa yang kuat, maju dan beradab. Mustahil masyarakat atau bangsa akan berubah menjadi baik kalau tidak dimulai dengan memperbaiki dan membenahi sistem pendidikannya. Jika umat Islam mau mencermati sejarahnya maka mereka tidak akan mendapatkan suatu sistem pendidikan yang lebih ideal dan lebih unggul selain dari sistem pendidikan Islam.

\section{F. Kesimpulan}

Dari pemaparan makalah di atas penulis dapat mengambil beberapa kesimpulan berikut:

1. Manusia diciptakan Allah untuk suatu tujuan yang besar dan misi yang penting yaitu beribadah kepada Allah Ta'ala semata.

2. Pengertian ibadah sangatlah luas dan tidak hanya terbatas pada ritual-ritual khusus semata. Semua aktivitas manusia yang dilakukan dalam rangka mewujudkan ketaatan kepada Allah Ta'ala dan sejalan dengan ridha Allah maka ia termasuk ibadah. Sehingga ibadah dalam Islam jangkauannya menyentuh semua aspek kehidupan dan mencakup seluruh gerak dan semua aktivitas yang dapat meningkatkan kualitas kehidupan manusia atau mensejahterakan manusia.

3. Semua pekerjaan bermanfaat yang dilakukan seorang muslim demi pengabdiannya kepada masyarakat, atau menolong personilDr. Shalih Abu Arrad, Pengantar Pendidikan Islam, Alih bahasa : Saiful
Rahim, M.A, Penerbit P.T Marwah Indo Media, Bogor, hlm. 65. 
personilnya, khususnya mereka yang tergolong kaum dhu'afa' dan papa juga merupakan salah satu bentuk ibadah.

4. Ibadah terbagi menjadi dua yaitu 'ibadah mahdhoh dan 'ibadah ghairu mahdhoh. Ibadah mahdhoh adalah ibadah yang bersifat ritual (sya'aa'ir) yang tata-cara (kaifiyat) dan bentuknya telah diajarkan dan dicontohkan oleh Rasulullah shallallahu 'alaihi wasallam seperti bersuci, shalat, puasa, zakat, haji, 'umroh, i'tikaf, dan sebagainya.

Sedangkan 'ibadah ghairu mahdhoh adalah ibadah yang bersifat umum yaitu semua amal kebaikan yang diridhai dan dicintai Allah Ta'ala seperti menanam tanam-tanaman yang bermanfaat bagi manusia, memudahkan urusan kaum muslimin, tolong menolong dalam kebaikan, dan sebagainya. Bahkan kebiasaan yang mubah (al-'adah) pun bernilai ibadah jika diniatkan sebagai bekal untuk taat kepada Allah. Misalnya, makan dan minum, tidur, jual beli, bekerja mencari nafkah dan sebagainya.

5. Dalam konteks hubungan dengan Rabb-nya manusia adalah hamba Allah. Sedangkan dalam konteks hubungan dengan alam semesta (kaun) ia adalah khalifah. Oleh karena itu dapat dikatakan bahwa tujuan hidup manusia adalah menunaikan penghambaan dan pengabdian -dalam makna yang luas- kepada Allah Ta'ala. Sedangkan perannya di muka bumi adalah sebagai khalifah (pemimpin) di alam semesta ini.

6. Tujuan pendidikan hendaknya selaras dan sejalan dengan tujuan hidup manusia karena pendidikan adalah salah satu bagian dari kehidupan itu sendiri.

7. Tujuan pendidikan dalam pandangan Islam adalah menumbuhkan manusia-manusia yang shalih dan senantiasa mengabdi (beribadah) kepada Allah atas dasar ilmu dan petunjuk. Juga, untuk membangun manusia-manusia yang mampu memakmurkan bumi demi kemaslahatan bersama serta mejalankan tugas-tugas kekhalifahan di muka bumi sesuai dengan manhaj Allah dan syari'at-Nya yang lurus. 


\section{DAFTAR PUSTAKA}

Al-Ashfahani, Ar-Raghib, Mufradaat Al-Qur'an, Riyadh: Al-Maktabah Asy-Syamilah.

Al-Baghowi, Al-Husain Bin Mas'ud, Ma'aalim At-Tanzil, Riyadh: Dar At-Thayyibah.

Al-Jauziyah, Ibn Al-Qayyim, 1425 H, Al-Qashidah An-Nuniyyah, AlMaktabah Asy-Syamilah.

Al-Harrani, Ahmad Ibn Abdul Halim, Al-'Ubudiyah, Kairo: Maktabah Dar Al-Balagh.

Al-Thabari, Muhammad Bin Jarir, Jami' Al-Bayan Fi Ta'wil AlQur'an, Riyadh: Mu'assasah Ar-Risalah.

Al-Manawi, Muhammad Abdur Ra'uf, 1415 H, Faidh Al-Qadir Syarh Al-Jami' Ash-Shaghir, Beirut: Dar Al-Kutub Al-'Ilmiyyah.

Anis, Ibrahim, 1421 H, Al-Mu'jam Al-Wasith, Kairo: Dar Al-Ma'arif.

Arrad, Shalih Abu, Pengantar Pendidikan Islam, Bogor: P.T. Marwah Indo Media.

Fauzan, Shalih Bin, 2012, Aqidah Tauhid; Kitab At-Tauhid Lis Shaff Al-Awwal, Jakarta: Ummul Qura.

Qardhawi, Yusuf, 1999, Merasakan Kehadiran Tuhan, Yogyakarta: Mitra Pustaka.

Risalah Gusti. 